\title{
Temporal and spatial scales of variation in bacterioplankton assemblages of oligotrophic surface waters
}

\author{
Ian Hewson $^{1,2, *}$, Joshua A. Steele ${ }^{1}$, Douglas G. Capone ${ }^{1}$, Jed A. Fuhrman ${ }^{1}$ \\ ${ }^{1}$ Department of Biological Sciences and Wrigley Institute for Environmental Studies, University of Southern California, \\ 3616 Trousdale Parkway AHF 107, Los Angeles, California 90089-0371, USA \\ ${ }^{2}$ Present address: Department of Ocean Sciences, University of California Santa Cruz, 1156 High Street EMS D446, \\ Santa Cruz, California 95064 USA
}

\begin{abstract}
Marine bacterioplankton dominate microbial carbon biomass in surface waters of the oligotrophic ocean, yet there have been few studies examining rates of change in bacterioplankton assemblage composition in situ over time and across water masses. Temporal changes in bacterioplankton assemblage composition were investigated during 7 drifter studies of 24 to 360 h duration in the oligotrophic Gulf of Mexico, the North Pacific and the West Tropical Atlantic in 2001 to 2003 , using an assemblage fingerprinting technique, automated rRNA intergenic-spacer analysis (ARISA). The similarity indices between assemblages collected over time in the same drifter changed on average by a Sørensen index of $0.12 \mathrm{~d}^{-1}$ (comparing the presence/absence of operational taxonomic units, OTU) and a Whittaker index (comparing proportions in various OTU) of $0.17 \mathrm{~d}^{-1}$ per fingerprint, across all surface drifter studies. Fingerprints generated from 7 replicate bacterioplankton DNA samples collected at each of 2 stations were remarkably similar to each other, sharing a Whittaker index $>0.85$. Despite this consistency over small spatial scales $(<2 \mathrm{~km})$, no clear relationship was observed between the separation distance of sampling locations and similarity between assemblage fingerprints in the North Pacific and Atlantic gyres over mesoscales (10 to $3000 \mathrm{~km}$ ), oscillating around a mean of 0.38 to 0.47 for each gyre. Our results suggest that factors ultimately shaping assemblage composition are localized at spatial scales between a few kilometers and about $50 \mathrm{~km}$, i.e. this is a typical horizontal 'patch size', within which communities are relatively homogenous, perhaps because physical mixing (e.g. by eddies) may dominate over biological interactions. Our results also suggest that, while similar environmental factors may cause bacterioplankton assemblages to share a small portion of OTU between different sampling locations, biological factors selecting for particular bacterial types (e.g. viral lysis, grazing, antagonism, nutrition) may cause assemblage composition variability over short geographic distances.
\end{abstract}

KEY WORDS: Bacterioplankton · Variability $\cdot$ Spatial scale $\cdot$ Oligotrophic waters $\cdot$ ARISA

\section{INTRODUCTION}

Studies examining bacterioplankton assemblage diversity and composition in the open ocean and estuaries typically capture 'snapshots' of biogeographic patterns by sampling at single stations (Giovannoni et al. 1990, Venter et al. 2004), or at the same station over multiple sampling times (Fuhrman et al. 2002, Riemann \& Middelboe 2002). Ocean surface waters are dynamic, because they are both laterally advected (Lagrangian motion), and vertically mixed over rela- tively short time scales. Because the chemical and biotic composition of different water masses is variable, composition of bacterioplankton assemblages may be patchy, even at small scales. The composition of bacterioplankton assemblages on very small scales (i.e. micrometers) has been demonstrated to vary remarkably (Long \& Azam 2001b), possibly associated with aquatic gel surfaces. Yet even though there is apparent microscale patchiness, few studies have examined spatio-temporal variability in bacterioplankton assemblage composition in the oligotrophic ocean. 
Given that most of the ocean can be considered oligotrophic, and that bacterioplankton play critical ecological roles in such environment, it is important to understand the relationship between this variability and environmental forcing. The diversity patterns of the dominant biomass component of one of the world's most extensive habitats is of fundamental interest. There are practical questions about the commonality of bacterial communities in different ocean locations, which is often assumed to be consistent without supporting evidence.

Bacterioplankton taxonomic composition is believed to result from selective environmental factors, such as resource availability (i.e. quantity and quality) (Torsvik et al. 2002), the physical environment (e.g. temperature, illumination, salinity), selective loss factors (e.g. grazing: Sherr \& Sherr 1994, Simek et al. 2001, Zhubkov \& Lopez-Urrutia 2003; viral lysis: Proctor \& Fuhrman 1990, Suttle et al. 1990, Bratbak et al. 1992, Fuhrman 1992, Thingstad \& Lignell 1997), and physical disturbance. There is little information about the time scale on which these factors effect changes in bacterioplankton assemblage composition. Containment alone of bacterioplankton in bottle incubations (Schwalbach et al. 2004, Winter et al. 2004) and field enclosures (Hewson et al. 2003) caused significant shifts in assemblage composition in some studies, on time scales from days (fast-growing bacterioplankton) to weeks (slow-growing bacterioplankton), while in another study few shifts were noted over $48 \mathrm{~h}$ containment (Lee \& Fuhrman 1987). The mechanisms causing these shifts remain unclear. Comparison of bacterioplankton assemblages incubated in the light and dark has been shown to cause shifts in assemblage composition after only $5 \mathrm{~d}$ in oceanic bacteria (Schwalbach et al. 2005). Addition of inorganic nutrients to large mesocosm enclosures has been demonstrated to cause community shifts after a 1 wk in Florida Bay (Hewson et al. 2003), while addition of concentrated viruses to bottle incubations caused little effect upon assemblage structure after $2 \mathrm{~d}$ in slow-growing bacterioplankton (Schwalbach et al. 2004, Winter et al. 2004), but significantly altered community structure of phytodetritalassociated biofilm communities in a nepheloid layer within Florida Bay after 2 d (Hewson et al. 2003). Thus, ecological factors may select for particular taxa in assemblages over a variety of time scales.

There is also the question of how mixing processes may affect composition (Fig. 1). Mixing of different bacterioplankton assemblages between 2 water masses may be analagous to mixing of different water mass end-members containing dissimilar physicochemical characteristics. If 2 completely dissimilar end-member assemblages are mixed over large spatial scales, then it might be expected that these would be

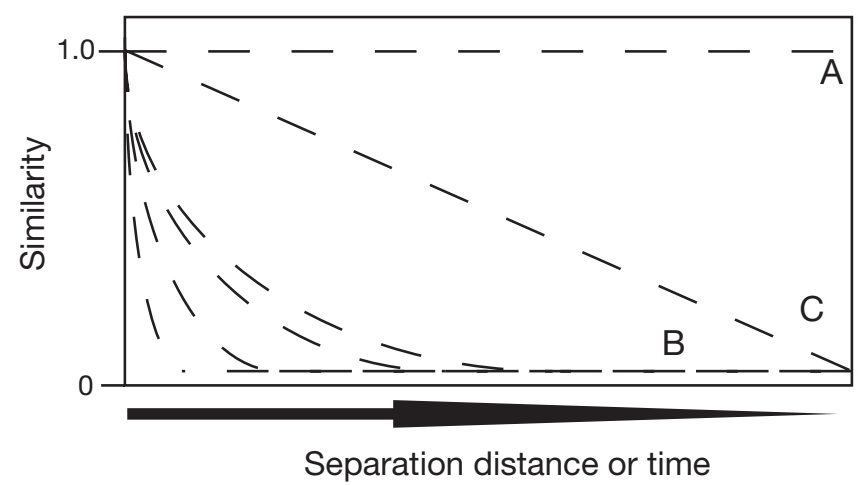

Fig. 1 Simulated relationship between similarity and separation distance; 3 types of dynamics are hypothesized. A: completely homogeneous communities, resulting in similarity index of 1.0 for all separation distances or times; $\mathrm{B}$ : heterogeneous communities, where decay in similarity to random association is determined by how patchy the dynamics are; C: heterogeneous communities, where distinct communities are mixed by processes like diffusion and advection over space. In the context of temporal scales, A represents unchanging assemblages, B heterogeneous and rapidly changing assemblages with no oscillations, and $\mathrm{C}$ gradual drift and linear end-member mixing

conservatively mixed (i.e. linear decrease in similarity between assemblage fingerprints with distance) if the time scale of mixing were significantly faster than generation times, or if conditions after mixing still permitted bacteria from both end-members to continue growing and dying near their pre-mixing rates (Fig. 1). The relative gradient of similarity-separation distance mixing plots therefore may indicate spatial scales of assemblage change. Similarly, comparison of the time separation between assemblage fingerprints generated from DNA collected within the same water mass may indicate temporal scales of bacterioplankton assemblage change.

The aim of this study was to examine spatiotemporal scales of assemblage change in oligotrophic water masses. We hypothesized that since the environment presumably selects for particular bacterial taxa, only small variability in assemblage composition would occur over short time and spatial scales. We addressed this hypothesis using 2 approaches, separating temporal from spatial changes in assemblage composition. To examine temporal changes in composition, bacterioplankton assemblages were examined while following four surface and three $150 \mathrm{~m}$ deep drifting array deployments in the Gulf of Mexico, North Pacific and West Tropical Atlantic Oceans over time scales of 24 to $360 \mathrm{~h}$. To examine spatial scales of change, we examined the relationship between pairwise similarity of assemblages collected ca. 2 to $3000 \mathrm{~km}$ apart and their spatial separation in 2 gyres (the West Tropical Atlantic and North Pacific) and 
along a $1800 \mathrm{~km}$ transect between the Arafura Sea and Coral Sea, which crosses between 2 major water masses (western Pacific and Indian Oceans) separated by a ca. $20 \mathrm{~m}$ deep sill interface with little lateral advection (Wolanski et al. 1995).

\section{MATERIALS AND METHODS}

Sampling locations. Samples from the transect between the Arafura Sea and the Coral Sea were obtained on board the RV 'Maurice Ewing' in November 1999 (Fig. 2) and in the North Pacific on board the RV 'Ka'imikai-o-Kanaloa' (June 2002), the RV 'Kilo Moana' (September to October 2002) and the RV 'Roger Revelle' (July to August 2003), and in the West Tropical Atlantic on board the RV 'Seward Johnson' in April to May 2003. The bacterioplankton assemblage DNA from the Gulf of Mexico was sampled on board the RV 'Walton Smith' in July 2001 and on board the RV 'Pelican' in June 2003.

Surface Lagrangian drifters with radio-position telemetry were deployed in the eastern Gulf of Mexico and followed continuously for $4 \mathrm{~d}$ in 2001 and for $3 \mathrm{~d}$ and $2 \mathrm{~d}$ in 2003. Drifting arrays (150 m depth) with $\operatorname{Argos}^{\circledR}$ surface transmitters were deployed in the North Pacific subtropical gyre on board the RV 'Kilo Moana' in September and October 2002 and sampled after 3 to $10 \mathrm{~d}$. One surface and one $150 \mathrm{~m}$ deep drifter study was also conducted in the West Tropical Atlantic aboard the RV 'Seward Johnson' in April/May 2003 and samples were taken after 3 to $20 \mathrm{~d}$. During all drifter studies, seawater was collected within $50 \mathrm{~m}$ of the drifters, using Niskin bottles mounted to a CTD

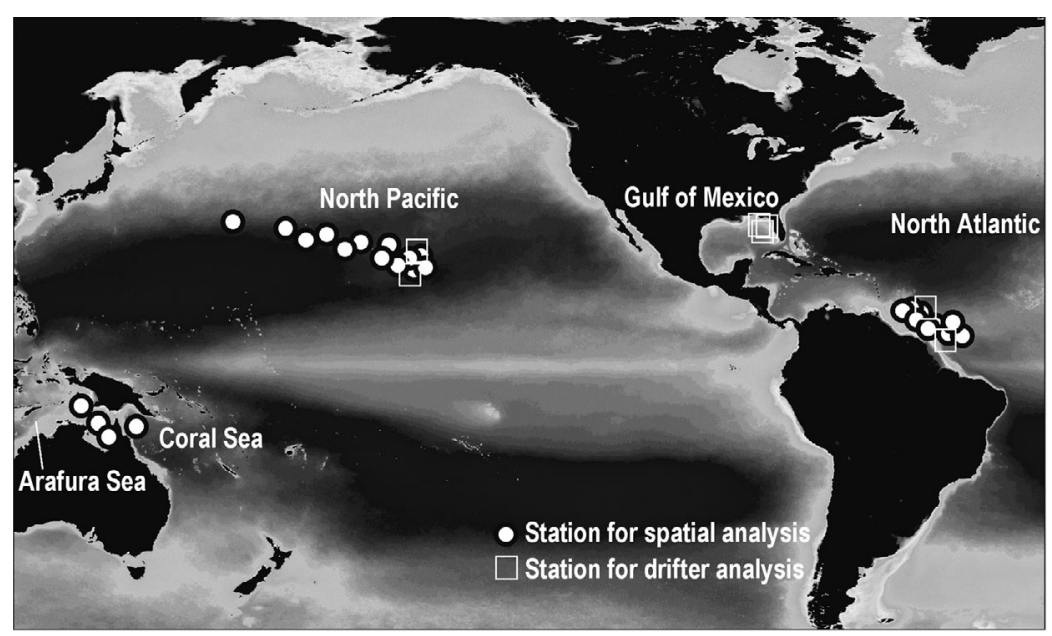

Fig. 2. Locations of drifter experiments in 2001 to 2003, and location of sampling stations in the North Pacific Ocean, North Atlantic Ocean, and on the Arafura Sea-Coral Sea transect in 1999. Background image is a SeaWiFS map of 2 yr mean chlorophyll a concentration, whereby darker hues indicate lower concentrations array, and drained immediately into acid-washed and seawater-rinsed low-density polyethylene carboys. These were kept in an outdoor flow-through incubator to maintain ambient surface water temperature and $25 \%$ attenuated incident irradiance prior to processing for bacterioplankton analysis, which occurred within $2 \mathrm{~h}$ of sampling. To determine the extent of spatial microheterogeneity, 7 seawater samples were also collected over a period of approximately $120 \mathrm{~min}$ at each of 2 North Pacific locations in 201 polycarbonate carboys in September 2002. Carboys (PC, 20 l) were placed open into a PVC pipe basket deployed about $3 \mathrm{~m}$ off the starboard side by crane and immersed to a depth of $1 \mathrm{~m}$ while the research vessel moved at ca. $1 \mathrm{~km} \mathrm{~h}^{-1}$ in the direction of sampling. Once retrieved, the carboys were immediately capped and kept in the dark in a flow-through outdoor incubator at $50 \%$ attenuated irradiance until processing (within approx. $2 \mathrm{~h}$ of collection). Bacterioplankton production was measured in triplicate incubations by ${ }^{3} \mathrm{H}$-leu incorporation (Kirchman et al. 1985, Simon \& Azam 1989).

DNA extraction and assemblage analysis. Bacteria were collected by filtering 201 of seawater serially through $1.2 \mu \mathrm{m}$ A/E glass-fiber filters, onto $0.22 \mu \mathrm{m}$ Durapore low-protein binding filters. All filters were immediately placed into sterile Whirl-Pak bags and frozen at $-80^{\circ} \mathrm{C}$ prior to analysis. DNA was extracted from the Durapore filter using the protocols of Fuhrman et al. (1988). Briefly, $500 \mu \mathrm{l}$ STE (100 mM $\mathrm{NaCl}, 10 \mathrm{mM}$ Tris, $1 \mathrm{mM}$ EDTA):10\% sodium dodecylsulfate (9:1) were added to the microcentrifuge tubes and sterivex filters, which were placed in a boiling water bath for 2 min to lyse bacterial cells. The liquid fraction was then transferred to a new microcentrifuge tube and DNA was precipitated at $-20^{\circ} \mathrm{C}$ overnight after addition of $150 \mu \mathrm{l} 10.5 \mathrm{M} \mathrm{NH} \mathrm{NHAC}_{4} \mathrm{O}$ and $1 \mathrm{ml}$ 100\% EtOH. After precipitation, samples were spun at 12000 $\times g$ for $30 \mathrm{~min}$ at $4^{\circ} \mathrm{C}$ to pellet the DNA. Pellets were then air-dried and resuspended in $200 \mu \mathrm{TE}(\mathrm{pH}$ 7.8). Resuspended DNA was then extracted sequentially with $200 \mu \mathrm{l}$ phenol, $200 \mu \mathrm{l}$ phenol:chloroform (10:1), and then $200 \mathrm{ul}$ chloroform:isoamyl alcohol (24:1). Samples were then precipitated again overnight with $50 \mu \mathrm{l}$ 10.5M $\mathrm{NH}_{4} \mathrm{OAc}$ and $500 \mu \mathrm{l} \mathrm{EtOH}$. After this precipitation, samples were spun at $12000 \times g$ for $30 \mathrm{~min}$ at $4^{\circ} \mathrm{C}$, and vacuum-desiccated; the pelleted DNA was then resuspended in $50 \mu \mathrm{TE}(\mathrm{pH}$ 7.8) at $37^{\circ} \mathrm{C}$ for $2 \mathrm{~h}$, then stored at $-80^{\circ} \mathrm{C}$ before use. 
Automated rRNA intergenic-spacer analysis (ARISA) was conducted on $10 \mathrm{ng}$ extracted DNA, measured by Pico Green (Molecular Probes) fluorescence (Fisher \& Triplett 1999). The internally transcribed spacer (ITS) region (plus about 285 bases of $16 \mathrm{~S}$ and 23S rRNA) of DNA extracts was amplified using the polymerase chain reaction (PCR). PCR was carried out in $50 \mu \mathrm{l}$ reactions using $1 \times$ PCR buffer, $2.5 \mathrm{mM} \mathrm{MgCl}_{2}, 250 \mu \mathrm{M}$ of each deoxynucleotide, $200 \mathrm{nM}$ each of Universal Primer 16s-1392F (5'-G(C/T)ACACACCGCCCGT-3') and Bacterial Primer 23s-125R labeled with a 5' TET (5'-GGGTT(C/G/T) CCCCATTC(A/G)G-3'), 2.5 U Taq polymerase (Promega) and BSA (Sigma No. 33036, $40 \mathrm{ng}^{-1} \mathrm{l}^{-1}$ final conc.). These primers targeted specifically bacteria; hence, archaea are not included in our analysis. Thermocycling was preceded by a 3 min heating step at $94^{\circ} \mathrm{C}$, followed by 30 cycles of denaturing at $94^{\circ} \mathrm{C}$ for $30 \mathrm{~s}$, annealing at $55^{\circ} \mathrm{C}$ for $30 \mathrm{~s}$, extension at $72^{\circ} \mathrm{C}$ for $45 \mathrm{~s}$, with a final extension step of $7 \mathrm{~min}$ at $72^{\circ} \mathrm{C}$. The calculated melting temperature of both primers was approximately $52^{\circ} \mathrm{C}$. PCR amplification products were purified in Qiagen MinElute PCR purification kits, then diluted to $5 \mathrm{ng} \mu^{-1}$ as measured by Pico Green fluorescence. Products were then run in duplicate for $5 \mathrm{~h}$ on an ABI 377XL automated sequencer (Avaniss-Aghajani et al. 1994) with 6-carboxyfluorescein (FAM) labeled Bioventures (Murfreesburo) standards. The sequencer electropherograms were then analyzed using ABI Genescan software.

Statistical analysis of molecular fingerprints. Fragments less than $400 \mathrm{bp}$, and those less than 5 times baseline fluorescence in height, were eliminated from our analyses since they could not be distinguished from instrument 'noise' (Hewson \& Fuhrman 2004). With these criteria, an operational taxonomic unit (OTU) exceeded the baseline when it contributed $>0.09 \%$ of total amplified DNA fluorescence. The area under each peak was then expressed as a percentage of the total integrated area under the electropherogram. Simpson's reciprocal index $(D)$, and Sørensen's index were calculated manually (Legendre \& Legendre 1998) according to:

$$
D=\left[\sum_{i=1}^{\mathrm{n}}\left(P_{i}\right)^{2}\right]^{-1}
$$

Sørensen's index $=2 W /\left(a_{1}+a_{2}\right)$

where $P_{i}$ is the fraction of each peak of total integrated area, $W$ is the number of shared ITS peaks between Populations 1 and 2, and $a_{1}$ and $a_{2}$ are the total number of different ITS lengths in Populations 1 and 2, respectively. Whole communities (i.e. all OTUs, each comprising $>0.09 \%$ of total amplified DNA) were compared by calculating Whittaker's index of association $\left(S_{\mathrm{w}}\right)$ using the equation from Legendre \& Legendre (1998):

$$
S_{\mathrm{w}}=1-\sum_{i=1}^{\mathrm{n}} \frac{\left(b_{i 1}-b_{i 2}\right)}{2}
$$

where $b_{1}$ and $b_{2}$ are the percentage contributions to amplified DNA of the ith OTU in Samples 1 and 2 , respectively. This index scales from 0 (completely different) to 1 (identical).

To account for variability in size associated with standards, ARISA fingerprints were binned using windows of $\pm 1 \mathrm{bp}$ from 400 to $700 \mathrm{bp}, \pm 2 \mathrm{bp}$ from 700 to $1000 \mathrm{bp}$, and $\pm 5 \mathrm{bp}>1000 \mathrm{bp}$. Since binning starting at a single window frame may cause OTU separated by $1 \mathrm{bp}$ to fall into different windows, we binned 10 times, each time beginning the bin window frame at $+1 \mathrm{bp}$ (Hewson \& Fuhrman 2006). The Whittaker \& Sørensen indicies were calculated for all pairwise comparisons in all 10 window frames. Since binning implies homogeneous variance in similarity between 2 random assemblages, we used the maximum similarity in all pairwise samples. Cluster-analysis was conducted using the XLStat (AddinSoft SARL) program using either the Sørensen or Whittaker index and clustering via the unweighted pair-group method using mean average (UPGMA) (Sokal \& Rohlf 1995). The pairwise distance between sampling locations based upon latitude and longitude was determined using the Le Progiciel R statistical analysis program (University of Montreal, www.bio.umontreal.ca/casgrain/R/).

\section{RESULTS}

\section{Gulf of Mexico drifter studies}

Bacterioplankton assemblage fingerprints changed over time in 3 drifter deployments on the West Florida Shelf (Table 1, Fig. 3). ARISA fingerprint richness and diversity also changed over drifter sampling (Table 2). Assemblage fingerprints shared on average $( \pm \mathrm{SE})$ a Sørensen index of $0.80 \pm 0.03$ and a Whittaker index of $0.73 \pm 0.04$ for all 3 drifter studies. Assemblage fingerprints changed the most during temporal studies in the first drifter in 2001, but were remarkably similar over the second and third studies in 2003. ARISA fingerprints were also different between 2001 and 2003, and shared a Whittaker index of only $0.41 \pm 0.02$, and a Sørensen index of $0.58 \pm 0.01$ (i.e. interannual difference). The pairwise similarity between assemblages was significantly and negatively correlated with elapsed time (Fig. 3).

\section{North Pacific and Atlantic drifting array studies}

Assemblage fingerprints from drifter studies in the Pacific Oceans and the West Tropical Atlantic changed between the beginning and end of the study period; 
Table 1. Changes in bacterioplankton assemblage composition over time in drifter studies. Similarity is given as fraction of shared, total, amplified DNA between original and final assemblage fingerprints (Whittaker index) and fraction of shared operational taxonomic units (OTUs) (Sørensen index) in the same comparison. Bacterial production rate is given as $\times 10^{6}$ cells ml $\mathrm{m}^{-1} \mathrm{~d}^{-1}$. Mean daily change was calculated for all data by first dividing complement of similarity index by duration for each drifter study, then calculating mean (and SE) across all drifter studies separately at surface and at $150 \mathrm{~m}$. This rate assumes linear change in similarity over duration of drifters. nd: not determined

\begin{tabular}{|c|c|c|c|c|c|c|c|c|c|c|c|}
\hline \multirow[t]{2}{*}{$\begin{array}{l}\text { Location } \\
\text { Study no. }\end{array}$} & \multirow[t]{2}{*}{ Start date } & \multicolumn{2}{|c|}{$\begin{array}{l}\text { Starting } \\
\text { position }\end{array}$} & \multicolumn{2}{|c|}{$\begin{array}{l}\text { Finishing } \\
\text { position }\end{array}$} & \multirow{2}{*}{$\begin{array}{c}\text { Elapsed } \\
\text { distance } \\
(\mathrm{km})\end{array}$} & \multirow{2}{*}{$\begin{array}{c}\text { Elapsed } \\
\text { time } \\
\text { (h) }\end{array}$} & \multirow[t]{2}{*}{$\begin{array}{l}\text { Bacterial } \\
\text { prod. rate }\end{array}$} & \multirow[t]{2}{*}{$\begin{array}{l}\text { Drifter } \\
\text { depth }\end{array}$} & \multicolumn{2}{|c|}{$\begin{array}{c}\text { Similarity between } \\
\text { assemblages }\end{array}$} \\
\hline & & Lat. & Long. & Lat. & Long. & & & & & Whittaker & Sørensen \\
\hline \multicolumn{12}{|c|}{ Gulf of Mexico } \\
\hline \multirow[t]{2}{*}{1} & 8 Jul 01 & 26.47 & 84.39 & 26.32 & 84.13 & 31.17 & 24 & nd & Surface & 0.44 & 0.56 \\
\hline & & & & & & & 72 & & & 0.73 & 0.73 \\
\hline \multirow[t]{3}{*}{2} & 6 Jun 03 & 27.90 & 84.81 & 27.85 & 84.50 & 30.41 & 24 & nd & Surface & 0.87 & 0.95 \\
\hline & & & & & & & 48 & & & 0.81 & 0.88 \\
\hline & & & & & & & 72 & & & 0.72 & 0.78 \\
\hline 3 & 10 Jun 04 & 27.85 & 84.50 & 27.92 & 84.81 & 31.40 & 24 & nd & Surface & 0.74 & 0.90 \\
\hline \multicolumn{12}{|c|}{ North Pacific Gyre } \\
\hline 4 & 2 Oct 02 & 23.75 & 159.47 & 23.57 & 157.65 & 187.10 & 240 & $0.09-0.12$ & $150 \mathrm{~m}$ & 0.74 & 0.77 \\
\hline 5 & 8 Oct 02 & 20.51 & 155.47 & 20.10 & 156.44 & 110.64 & 48 & $0.17-0.19$ & $150 \mathrm{~m}$ & 0.75 & 0.77 \\
\hline \multicolumn{12}{|c|}{ West Tropical Atlantic } \\
\hline 6 & 4 May 03 & 7.51 & 54.19 & 9.92 & 57.89 & 487.53 & 360 & $0.09-0.19$ & Surface & 0.68 & 0.60 \\
\hline 7 & 18 May 03 & 10.64 & 54.27 & 10.87 & 54.98 & 81.76 & 72 & $0.16-0.53$ & $150 \mathrm{~m}$ & 0.42 & 0.31 \\
\hline \multicolumn{4}{|c|}{ Surface mean change $d^{-1}$} & & & & & & & 0.17 & 0.12 \\
\hline & & & & & & & 0.07 & 0.06 \\
\hline \multicolumn{4}{|c|}{150 m mean change $\left(\mathrm{d}^{-1}\right)$} & & & & & & & 0.11 & 0.12 \\
\hline \multicolumn{2}{|l|}{$\mathrm{SE}$} & & & & & & & & & 0.05 & 0.06 \\
\hline
\end{tabular}

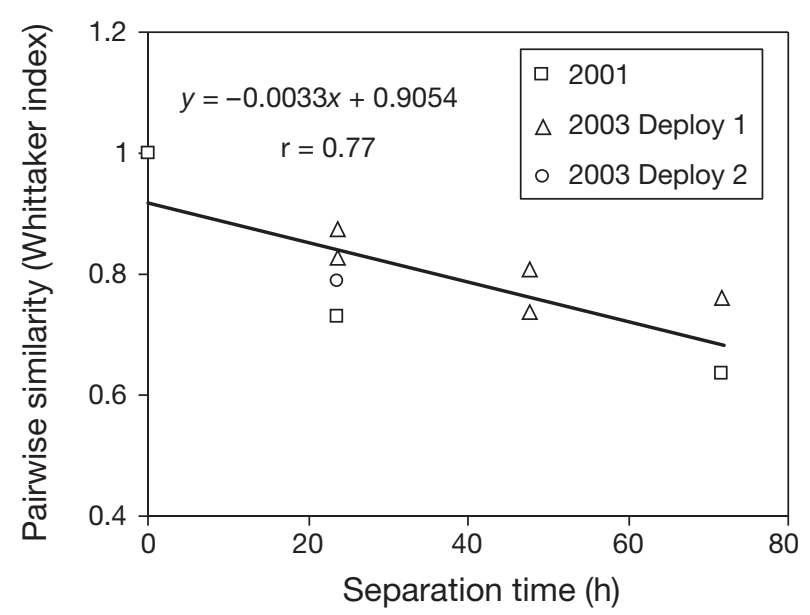

Fig. 3. Comparison of pairwise similarity between fingerprints with elapsed time between samplings for drifter experiments in the Gulf of Mexico

however, the magnitude of change was different in different regions. In the North Pacific, $150 \mathrm{~m}$ assemblage fingerprints shared a Whittaker index of ca. 0.75 after 48 to $280 \mathrm{~h}$, while in surface waters of the Atlantic, a Whittaker index of only 0.42 to 0.68 was shared after 72 to $360 \mathrm{~h}$ (Table 1). Calculated surface water growth rates of bacterioplankton during the North Pacific drifter deployment changed from 0.1 to $0.2 \mathrm{~d}^{-1}$, while in the Atlantic they changed from 0.1 to $0.5 \mathrm{~d}^{-1}$ (I. Hewson unpubl. data).

\section{Spatial variability in bacterioplankton assemblage composition}

At 2 stations where 7 samples were collected over $2 \mathrm{~h}$, while the ship was drifting with the current at ca. $1 \mathrm{~km} \mathrm{~h}^{-1}$ (i.e. samples were separated at most by a few kilometers), bacterioplankton assemblage ARISA fingerprints each contained 37 to 49 OTU $(44.6 \pm 1.3$, mean \pm SE) at the first station and 38 to 48 OTU (43.3 \pm 1.4) at the second station. The fingerprint Simpson's reciprocal index ranged from 9.5 to $14.2(11.9 \pm 0.6)$ at the first site and 8.2 to $11(9.7 \pm 0.3)$ at the second site. Samples shared an average Sørensen index of $0.92 \pm$ 0.01 (presence/absence) between samples across both locations, and a Whittaker index of $0.90 \pm 0.01$ (mean \pm SE) (Fig. 4), which is statistically indistinguishable from the similarity between analytical replicate ARISA fingerprints (Whittaker index of 0.89).

ARISA fingerprint richness and diversity varied across the transect from the Arafura Sea to the Coral Sea from 25 to 63 OTU per fingerprint and the Simpson's reciprocal indices from 4.6 to 25.2 , but diversity and richness had no consistent pattern across the transect. In all pairwise comparisons between assemblages within the Arafura-Coral Sea transect, assemblages shared a Whittaker index of $0.34 \pm 0.02$ and a Sørensen index of $0.51 \pm 0.02$.

We examined the similarity between sampling locations from each region separately by using pairwise 
Table 2. Diversity indices of automated rRNA intergenic-spacer analysis (ARISA) fingerprints from drifter deployments. The mean ( \pm SE) is indicated where sampling occurred on $>2$ timepoints

\begin{tabular}{|lccccc|}
\hline \multirow{2}{*}{$\begin{array}{l}\text { Location } \\
\text { Study no. }\end{array}$} & \multicolumn{2}{c}{ No. OTU } & & \multicolumn{2}{c|}{ Simpson's index } \\
Gange & Mean & & Range & Mean \\
\hline Gulf of Mexico & & & & \\
1 & $87-196$ & $154.6( \pm 34.1)$ & $16.4-23.3$ & $19.7( \pm 2.0)$ \\
2 & $125-158$ & $138.7( \pm 9.9)$ & $18.6-24.4$ & $21.4( \pm 1.7)$ \\
3 & $89-99$ & & $13.9-16.7$ & \\
North Pacific Gyre & & & & \\
4 & $86-89$ & & $19.2-24.1$ & \\
5 & $67-81$ & & & \\
West Tropical Atlantic & & & $9.7-16.6$ & \\
6 & $45-87$ & & & & \\
7 & $69-86$ & & & & \\
\end{tabular}

perature in the North Pacific, West Tropical Atlantic and Coral-Arafura Sea transect ranged from 25.4 to $27.5^{\circ} \mathrm{C}$ $($ mean $=26.5 \pm 0.1, \mathrm{n}=32), 26.7$ to $28.1^{\circ} \mathrm{C}$ $(27.4 \pm 0.1, \mathrm{n}=16)$, and 29.1 to $30.1^{\circ} \mathrm{C}$ (mean $=29.7 \pm 0.2, \mathrm{n}=6$ ), respectively. The absolute change in both salinity and temperature increased with separation distance in the North Pacific Ocean and West Tropical Atlantic to approx. $500 \mathrm{~km}$, but was nonlinear at distances greater than approx. $500 \mathrm{~km}$ (Fig. 5). Along the Coral-Arafura Sea transect, salinity did not change predictably; however, temperature increased linearly along the length of the transect.
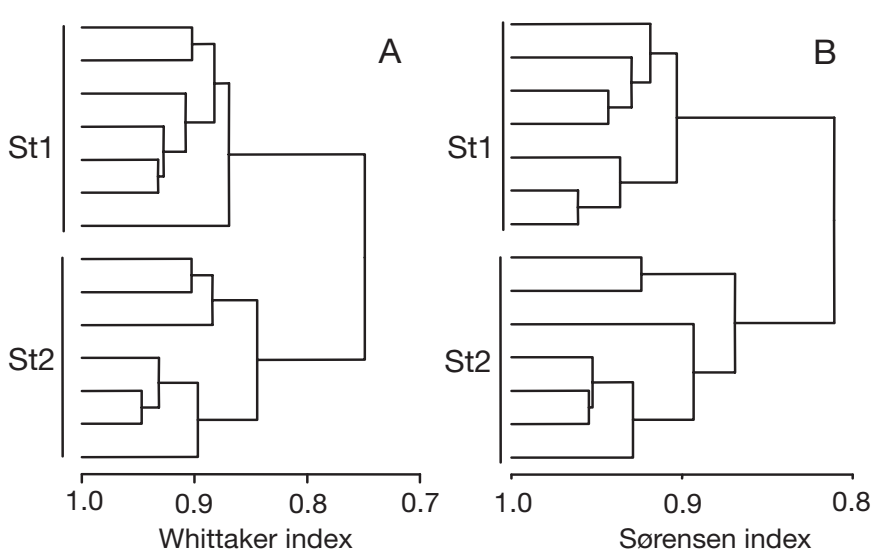

Fig. 4. Cluster analyses of bacterioplankton assemblage fingerprints generated from 7 samples collected next to each other, at each of 2 stations in the North Pacific Ocean. Clustering was performed using the (A) Whittaker index and (B) Sørensen index and the unweighted pair-group method using the unweighted pair-group mean average (UPGMA) analysis approach

similarity-separation distance plots, which conceptually indicate the extent and geographic scale of homogeneity or heterogeneity in assemblage composition (Fig. 1). The pairwise similarity between assemblage fingerprints was significantly and negatively correlated with separation distance between locations along the Arafura-Coral Sea transect $(r=0.77$, df $=17)$. Separation distance and pairwise similarity was not correlated in the North Pacific or Atlantic Oceans (Fig. 5).

To examine covariation in physicochemical parameters with the pairwise similarity-separation distance comparison, we compared pairwise differences in salinity and temperature between different stations. Salinity in the North Pacific, West Tropical Atlantic and Coral-Arafura Sea transect ranged from 34.7 to 35.6 $($ mean $=35.1 \pm 0.04, \mathrm{n}=32), 24.6$ to $36.4(32.9 \pm 0.7)$, and 33.6 to 34.3 (mean $33.9 \pm 0.1, \mathrm{n}=6$ ), respectively. Tem-

\section{DISCUSSION}

Our results demonstrate that bacterioplankton assemblages in oligotrophic waters are variable in time and space. Bacterioplankton assemblages were remarkably stable in some geographic locations, yet unstable in others, over short time scales within the same water mass. These data indicate that changes in assemblages are brought about by factors acting on short time scales on the order of days. Comparison of assemblage fingerprints over a transect between 2 water masses and during extensive spatial studies in the Pacific and West Tropical Atlantic Oceans suggest that different water masses typically contain different bacterial assemblages; however, within the same water mass, bacterioplankton assemblages are consistent on spatial scales of less than a few kilometers (i.e. the replicate seawater assemblages collected), yet patchy at scales of several kilometers or more. Therefore, factors causing variations in assemblage composition are probably inconsistent at scales greater than several kilometers or more, yet are consistent at spatial scales of less than a few kilometers.

\section{Potential errors associated with fingerprinting approaches}

It is possible that each OTU in ARISA fingerprints represents more than 1 taxon, since 2 or more bacteria may share the same ITS length, even if it is of different sequence (Fisher \& Triplett 1999). Similarly, bacterial taxa may contain more than 1 operon with different ITS lengths and therefore may appear as $>1$ OTU in our analysis (Crosby \& Criddle 2003). However, recent studies have demonstrated that slow-growing bacterial taxa, characteristic of oligo- 


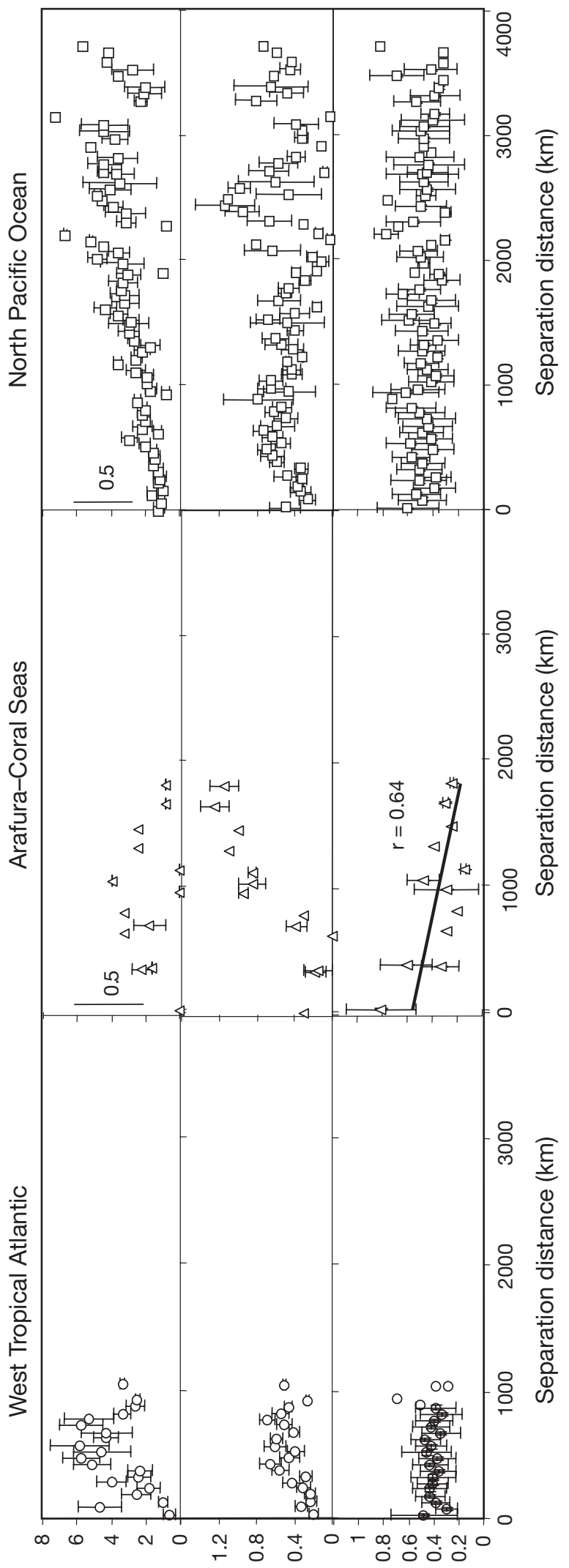

$\Delta$ Salinity $\quad \Delta$ Temperature Pairwise similarity

$\left({ }^{\circ} \mathrm{C}\right) \quad$ (Whittaker index) a

$$
\text { 费 }
$$

trophic waters, contain only 1 or 2 ITS regions of uniform length (Klappenbach et al. 2000, Brown et al. 2005). Bias in template-to-amplicon ratios may occur due to sequence heterogeneities because of guanine + cytosine content differences (Suzuki \& Giovannoni 1996, Polz \& Cavanaugh 1998, Suzuki et al. 1998). Finally, there may be differences in extractability between bacterioplankton cells, or gene rearrangements that preclude amplification which may cause some OTU to be underrepresented altogether in ARISA fingerprints (Polz et al. 1999). However, even if some taxa are missed, or are not proportionally represented, fingerprinting is reproducible (Moeseneder et al. 2001, Hewson \& Fuhrman 2004) and allows clear differences between assemblages to be observed. We do not believe PCR biases or extractability of cells affected our conclusions of change in assemblage composition over short time scales, or heterogeneity between assemblages between water masses and within oligotrophic oceanic gyres.

\section{Temporal changes in bacterioplankton assemblages}

During 3 drifter deployments in the Gulf of Mexico in 2001 and 2003 and separate drifters near the Hawaiian archipelago and West Tropical Atlantic, assemblage fingerprints remained remarkably stable over short time scales (days) in some studies, but also changed rapidly during others. In the first Gulf of Mexico drifter deployment in 2001 (Fig. 3), assemblage fingerprints were dissimilar to original assemblage fingerprints after only $24 \mathrm{~h}$. The second and third drifter deployments in 2003 had, by contrast, fewer changes in fingerprints over time than in 2001. Interestingly, shifts in the richness and diversity of bacterial assemblage fingerprints over time during most drifter deployments suggest that the relative dominance of OTU may change on short time scales ( $<1 \mathrm{~d})$. However, drifter deployments cannot account for small-scale eddies, mixing, and shear (O'Donnell et al. 1997). Therefore, some of our observed variability in bacterioplankton assemblage fingerprints could be due to intrusions of different water masses which became mixed and slowly diffused together.

Across all drifter deployments in the Gulf of Mexico, North Pacific and West Tropical Atlantic at the surface, assemblages changed by an average Whittaker index of $0.17 \pm 0.07$, and 
Sørensen index of $0.12 \pm 0.06 \mathrm{~d}^{-1}$ (mean $\pm \mathrm{SE}$ ) (Table 1). Interestingly, deeper drifters changed on the same temporal scale (Whittaker index of $0.12 \pm 0.06$ \& Sørensen index of $0.11 \pm 0.05$ ). The significant and negative correlation between assemblage fingerprints and elapsed time during drifter studies (Fig. 3) indicates that there is a slow drift of assemblage composition, punctuated over short time scales (h) by shortlived changes, possibly induced by biotic interactions. Bacterial community growth rates measured in the Pacific and West Tropical Atlantic drifter studies were approximately $0.2 \pm 0.04 \mathrm{~d}^{-1}$, and we might expect change on time scales of the assemblage generation. Measured bacterioplankton growth is an ensemble average across complex assemblages containing cells growing at a spectrum of rates (Luna et al. 2004). Therefore, it is not surprising that assemblages may change composition dynamically over short time scales, since slow-growing or rare taxa under typical conditions may form a larger component of the assemblage under conditions optimal for those taxa.

Bacterial assemblages are believed to be shaped by combinations of resource availability and quality (Torsvik et al. 2002), physical characteristics of water masses, interactions between bacterial taxa (Kjelleberg \& Givskov 2000, Long \& Azam 2001a), and selective loss factors (Thingstad \& Lignell 1997, Simek et al. 2001). Since the study of assemblage composition has only been possible since the advent of molecular techniques in the past 2 decades (Giovannoni et al. 1990, Fuhrman et al. 1992, 1993), there have been remarkably few studies examining the impact of these factors upon bacterial assemblage composition. Likely candidate mechanisms influencing assemblage composition over short time scales (i.e. $<24 \mathrm{~h}$ ) include interactions that can be characterized as 'bottom-up' from resource availability, interactions among bacteria, or those that are 'top-down' from grazing or viral attack.

\section{Spatial scales of heterogeneity of microbial communities}

Replicate bacterioplankton assemblage fingerprints, generated from DNA collected from the same location, contained similar communities with similar fingerprint diversity (Fig. 4 ). This indicates that at a single station, communities are more similar to each other than to other stations, as one might expect. However, microbial assemblages have been described as being heterogeneous on the micrometer scale (Long \& Azam 2001b, Seymour et al. 2004), both in terms of bacterial activity and assemblage composition. During an intense Lingulodinium polydrum bloom off San Diego, California, ten $2 \mu \mathrm{l}$ samples of seawater were com- pared by DGGE amplification, and shared between 40 and $90 \%$ of OTU between adjacent samples (Long \& Azam 2001b), while a previous study of bacterioplankton in a $10 \mathrm{~cm}^{2}$ patch of the Port River (Adelaide, Australia) using flow cytometry identified discrete zones of bacterial cells with large DNA content (presumably more 'active' bacteria) (Seymour et al. 2004). Long \& Azam (2001b) found much more homogeneity when several millimeters or more were examined, compared to a few microliters. Our data demonstrate that variability in homogenised (>1 l) samples over presumable meter to kilometer scales (maximum distance between the 7 carboy casts) was on average $<10 \%$ of total OTU and distribution of DNA fluorescence in fingerprints. It appears that there are mechanisms that make scales of more than a few centimeters remarkably consistent despite any micrometer variability, as if the adjacent micrometer scales average out to the same composition based upon some overall larger-scale properties. This probably is related to the scale of mixing in relation to the scale of growth and biotic interactions that affect composition. Patchiness in phytoplankton chlorophyll $a$ has been demonstrated numerically to be more variable over scales of a few kilometers than physicochemical parameters which characterise water masses. This may be due to the faster response time of phytoplankton compared to equilibration of physicochemical parameters (Mahadevan \& Campbell 2002).

\section{Comparison of bacterioplankton assemblage fingerprints across water masses}

Our results demonstrate that bacterial assemblage composition is patchy in marine surface waters. Similarity between bacterial assemblages within the same ocean basin varies with separation distance, which is more variable than changes in water mass physicochemical (salinity and temperature) characteristics. These data suggest that factors selecting for particular bacterial taxa exist on short spatial scales (shorter than between sampling locations). In contrast, bacterial assemblages within separate water masses may be selected for by different environmental conditions and may be considered end-member assemblages which are mixed at interfaces. This suggests that while basinscale factors (e.g. physicochemical conditions) may ultimately affect the assemblage composition of bacterioplankton, sub-basin-scale factors (e.g. phytoplankton blooms, interactions between bacteria and bacterivores and viruses) may cause within-basin variability in assemblage structure.

The significant and negative correlation between fingerprint similarity and separation distance between the Arafura Sea (a finger of the Indian Ocean) and the 
Coral Sea suggests that this region is a mixing transect of end-member assemblages in both these basins. The change in assemblage composition along the transect is also consistent with change in temperature, but not in salinity of waters. Mixing of 2 end-member assemblages would theoretically result in a gradual decrease in similarity with increasing separation distance, analagous to mixing of physical characteristics along environmental gradients (e.g. estuaries). The Torres Strait, a ca. $20 \mathrm{~m}$ deep sill separating the Arafura and Coral Seas, is a barrier to geographic dispersal of several organisms, and was closed altogether on several occasions in the Pleistocene (Chappell \& Shakleton 1986). This barrier has been demonstrated to have a significant impact upon gene flow in fish populations on either side of the strait (Chenoweth et al. 1998); however, the impacts of impedence upon plankton in this region is unknown. The regression between pairwise similarity and separation distance along this transect also contains regions of greater and less similarity, suggesting that selective factors upon bacterioplankton assemblage composition exist on short spatial scales, such as between adjacent sampling locations (i.e. less than approx. $100 \mathrm{~km}$ ).

The lack of relationship between separation distance and pairwise assemblage fingerprint similarity in both the West Tropical Atlantic and Pacific Oceans suggests that within the same ocean environment, bacterioplankton assemblages may be selected for by basinscale environmental conditions, but patchiness may be induced by sub-basin-scale selective factors. In these environments, advective mixing of assemblages (i.e. homogenisation) does not seem to cause enhanced similarity between adjacent assemblages, but rather a homogenous mixture of bacterial taxa may be acted upon by spatially variable selective factors, causing variability in assemblage structure between adjacent locations. It is interesting that the variability in assemblage composition observed in the North Pacific and Atlantic Oceans, and along the Arafura-Coral Sea transect occurs on the same magnitude as mesoscale eddies (Roemmich \& Gilson 2001, Martin 2003), which are shown as inflection points in salinity and temperature change plots at separation distance scales of ca. $500 \mathrm{~km}$.

Lagrangian motion of water masses has been argued to prohibit meaningful ecological interpretation of studies of assemblage composition in which only a small number of samples over large distances are collected and analysed (Falkowski \& de Vargas 2004). It should be noted that fingerprinting permitted a much larger number of samples to be analysed than could be practically expected from cloning and sequencing, with good coverage of each sample. Perhaps partly for this reason, our results appear to support some useful interpretations. Our study of bacterial assemblages across the Arafura-Coral Sea transect took place over $14 \mathrm{~d}$. The mean daily water motion over the Torres Strait towards the Coral Sea is $<1 \mathrm{~km} \mathrm{~d}^{-1}$ (Wolanski et al. 1995), indicating that the mixing of assemblages implied from the regression between pairwise similarity and separation distance is not affected by water motion over short time scales, but rather reflects longterm dispersal of bacterial OTU. Thus, sampling of bacterioplankton assemblages over wide geographic scales provides insight into ecological factors shaping communities, independent of short-term spatial and temporal changes in bacterial assemblage composition brought about by mixing. Interestingly, this also suggests that the variability and shift in assemblage composition noted in drifter deployments may also impact assemblages only on short time scales (i.e. the duration of these studies), but that on longer time scales assemblages may be more strongly influenced by geographical location and water mass characteristics.

\section{CONCLUSIONS}

Our results demonstrate that open ocean bacterioplankton assemblages are dynamic and patchy, and changes in assemblage composition occur over short temporal scales. However, these data indicate that processes causing changes in assemblages are homogeneous over horizontal spatial scales in the approximate range of meters to $\sim 5 \mathrm{~km}$, but are heterogeneous at scales $>50 \mathrm{~km}$. This horizontal 'patch size' probably corresponds in some way to physical eddy size, where mixing within the eddy generally homogenises bacterial composition on scales shorter than the generation time. Vertical changes occur on much smaller scales, as is typical of the stratified ocean (Moeseneder et al. 2001). Of possible factors causing changes in assemblages, interactions between bacteria (e.g. allelopathy) and with other organisms (i.e. biotic interactions) are potential candidates eliciting smallscale variations in assemblage composition. Finally, spatial analysis of assemblage composition across water mass interfaces and in the absence of oceanic barriers suggests that while basin-scale environmental conditions may influence bacterioplankton assemblage structure, spatially small-scale factors may cause patchiness of assemblages.

Acknowledgements. The authors gratefully acknowledge the assistance of the crews of the RV 'Walton Smith', RV 'Pelican', RV 'Kilo Moana', RV 'Roger Revelle' and RV 'Seward Johnson'; T. Gunderson, P.J. Morris, C. Heil, J. O'Neil, M. Mulholland, D. Bronk, E. Carpenter, K.E. Wommack, V. Coles and T. Peterson. Helpful conversations on interpretation were held with $\mathrm{C}$. 
Horner-Devine, B. Jenkins and J. Zehr. The authors thank the SeaWiFS Project (Code 970.2) and the Goddard Earth Sciences Data and Information Services Center/Distributed Active Archive Center (Code 902) at the Goddard Space Flight Center, Greenbelt, MD 20771, USA, for the production and distribution of SeaWiFS, respectively, in Fig. 2. These activities are sponsored by NASA's Earth Science Enterprise. This work was supported by NSF Microbial Observatories grant MCB0084231 awarded to J.A.F and D. Caron, NSF Biocomplexity grant OCE9981545 and OCE9981371 awarded to D.G.C., E. Carpenter, A. Subramaniam, and A. Michaels, NSF grant OCE0527034 awarded to J.A.F., D.G.C. and V. Coles, and grant NSF0095970 awarded to C. Heil. This work is in partial completion of a PhD by I.H. at the University of Southern California

\section{LITERATURE CITED}

Avaniss-Aghajani E, Jones K, Chapman D, Brunk C (1994) A molecular technique for identification of bacteria using small subunit ribosomal RNA sequences. Biotechniques $17: 144-149$

Bratbak G, Heldal M, Thingstad TF, Riemann B, Haslund OH (1992) Incorporation of viruses into the budget of microbial C-transfer. A first approach. Mar Ecol Prog Ser 83: 273-280

Brown MV, Schwalbach MS, Hewson I, Fuhrman JA (2005) Coupling 16S-ITS rDNA clone libraries and ARISA to show marine microbial diversity: development and application to a time series. Environ Microbiol 7:1466-1479

Chappell J, Shakleton NJ (1986) Oxygen isotopes and sea level. Nature 324:137-140

Chenoweth SF, Highes JM, Keenan CP, Lavery S (1998) When oceans meet: a teleost shows secondary intergradation at an Indian-Pacific Interface. Proc Soc Lond B 265: $415-420$

Crosby LD, Criddle CS (2003) Understanding bias in microbial community analysis techniques due to $r r n$ operon copy number heterogeneity. Biotechniques 34:790-802

Falkowski PG, de Vargas C (2004) Shotgun sequencing in the sea: a blast from the past? Science 304:58-60

Fisher MM, Triplett EW (1999) Automated approach for ribosomal intergenic spacer analysis of microbial diversity and its application to freshwater bacterial communities. Appl Environ Microbiol 65:4630-4836

Fuhrman JA (1992) Bacterioplankton roles in cycling of organic matter: the microbial food web. In: Falkowski PG, Woodhead AD (eds) Primary productivity and biogeochemical cycles in the sea. Plenum Press, New York, p 361-382

Fuhrman JA, Comeau DE, Hagstrom A, Chan AM (1988) Extraction of DNA suitable for molecular biological studies from natural planktonic microorganisms. Appl Environ Microbiol 54:1426-1429

Fuhrman JA, McCallum K, Davis AA (1992) Novel major archaebacterial group from marine plankton. Nature 356 : 148-149

Fuhrman JA, McCallum K, Davis AA (1993) Phylogenetic diversity of subsurface marine microbial communities from the Atlantic and Pacific Oceans. Appl Environ Microbiol 59:1294-1302

Fuhrman JA, Griffith JF, Schwalbach MS (2002) Prokaryotic and viral diversity patterns in marine plankton. Ecol Res 17:183-194

Giovannoni SJ, Britschgi TB, Moyer CL, Field KG (1990) Genetic diversity in Sargasso Sea bacterioplankton. Nature 345:60-63
Hewson I, Fuhrman JA (2006) Improved strategy for comparing microbial assemblage fingerprints. Microb Ecol 51:147-153

Hewson I, Fuhrman JA (2004) Bacterioplankton species richness and diversity along an estuarine gradient in Moreton Bay, Australia. Appl Environ Microbiol 70:3425-3433

Hewson I, Vargo GA, Fuhrman JA (2003) Bacterial diversity in shallow oligotrophic marine benthos and overlying waters: effects of virus infection, containment and nutrient enrichment. Microb Ecol 46:322-336

Kirchman D, Knees E, Hodson R (1985) Leucine incorporation and its potential as a measure of protein-synthesis by bacteria in natural aquatic systems. Appl Environ Microbiol 49:599-607

Kjelleberg S, Givskov M (2000) Communication systems as targets for biological control. Environ Microbiol 2:5-15

Klappenbach JL, Dunbar JM, Schmidt TM (2000) rRNA operon copy number reflects ecological strategies of bacteria. Appl Environ Microbiol 66:1328-1333

Lee S, Fuhrman JA (1987) Relationships between biovolume and biomass of naturally derived marine bacterioplankton. Appl Environ Microbiol 53:1298-1303

Legendre P, Legendre L (1998) Numerical ecology. Elsevier, Amsterdam

Long RA, Azam F (2001a) Antagonistic interactions among marine pelagic bacteria. Appl Environ Microbiol 67: $4975-4983$

Long RA, Azam F (2001b) Microscale patchiness of bacterioplankton assemblage richness in seawater. Aquat Microb Ecol 26:103-113

Luna GM, Dell'Anno A, Giuliano L, Danovaro R (2004) Bacterial diversity in deep Mediterranean sediments: relationship with the active bacterial fraction and substrate variability. Environ Microbiol 6:745-753

Mahadevan A, Campbell JW (2002) Biogeochemical patchiness at the sea surface. Geophys Res Lett 29(19): doi. 10.1029/2001GL014116

Martin AP (2003) Phytoplankton patchiness: the role of lateral stirring and mixing. Prog Oceanogr 57:125-174

Moeseneder MM, Winter C, Herndl GJ (2001) Horizontal and vertical complexity of attached and free-living bacteria of the eastern Mediterranean Sea, determined by $16 \mathrm{~S}$ rDNA and 16S rRNA fingerprints. Limnol Oceanogr 46:95-107

O'Donnell J, Allen AA, Murphy DL (1997) An assessment of the errors in Lagrangian velocity estimates obtained by FGGE drifters in the Labrador Current. J Atmosph Ocean Technol 14:292-307

Polz MF, Cavanaugh CM (1998) Bias in template-to-product ratios in multitemplate PCR. Appl Environ Microbiol 64: 3724-3730

Polz MF, Harbison C, Cavanaugh CM (1999) Diversity and heterogeneity of epibiotic bacterial communities on the marine nematode Eubostrichus dianae. Appl Environ Microbiol 65:4271-4275

Proctor LM, Fuhrman JA (1990) Viral mortality of marine bacteria and cyanobacteria. Nature 343:60-61

Riemann L, Middelboe M (2002) Stability of bacterial and viral community compositions in Danish coastal waters as depicted by DNA fingerprinting techniques. Aquat Microb Ecol 27:219-232

Roemmich D, Gilson J (2001) Eddy transport of heat and thermocline waters in the North Pacific: a key to interannual/decadal climate variability? J Phys Oceanogr 31:675-687

Schwalbach MS, Hewson I, Fuhrman JA (2004) Viral effects on bacterial community composition in marine plankton microcosms. Aquat Microb Ecol 34:117-127 
Schwalbach MS, Brown MV, Fuhrman JA (2005) Impact of light on marine bacterioplankton community structure. Aquat Microb Ecol 39:235-245

Seymour JR, Mitchell JG, Seuront L (2004) Microscale heterogeneity in the activity of coastal bacterioplankton communities. Aquat Microb Ecol 35:1-16

Sherr EB, Sherr BF (1994) Bacterivory and herbivory: key roles of phagotrophic protists in pelagic food webs. Microb Ecol 28:223-235

Simek K, Pernthaler J, Weinbauer MG, Hornák K, Dolan JR, Nedoma J, Masín M, Amann R (2001) Changes in bacterial community composition and dynamics and viral mortality rates associated with enhanced flagellate grazing in a mesoeutrophic reservoir. Appl Environ Microbiol 67: 2723-2733

Simon M, Azam F (1989) Protein content and protein synthesis rates of planktonic marine bacteria. Mar Ecol Prog Ser 51:201-213

Sokal RR, Rohlf FJ (1995) Biometry. The principles and practice of statistics in biological research. 3rd edn. Freeman, New York

Suttle CA, Chan AM, Cottrell MT (1990) Infection of phytoplankton by viruses and reduction of primary productivity. Nature 347:467-469

Suzuki MT, Giovannoni SJ (1996) Bias caused by template annealing in the amplification of mixtures of $16 \mathrm{~S}$ rRNA

Editorial responsibility: Fereidoun Rassoulzadegan (Contributing Editor), Villefranche-sur-mer, France genes by PCR. Appl Environ Microbiol 62:625-630

Suzuki MT, Rappé M, Giovannoni SJ (1998) Kinetic bias in estimates of picoplankton community structure obtained by measurements of small-subunit rRNA gene PCR amplicon length heterogeneity. Appl Environ Microbiol 64: $4522-4529$

Thingstad TF, Lignell R (1997) A theoretical approach to the question of how trophic interactions control carbon demand, growth rate, abundance and diversity. Aquat Microb Ecol 13:19-27

Torsvik V, Ovreas L, Thingstad TF (2002) Prokaryotic diversity-magnitude, dynamics and controlling factors. Science 296:1064-1066

Venter JC, Remington K, Heidelberg JF, Halpern AL and 19 others (2004) Environmental genome shotgun sequencing of the Sargasso Sea. Science 304:66-74

Winter C, Smit A, Herndl GJ, Weinbauer MG (2004) Impact of virioplankton on archaeal and bacterial community richness as assessed in seawater batch cultures. Appl Environ Microbiol 70:803-813

Wolanski E, Norro A, King B (1995) Water circulation in the Gulf of Papua. Cont Shelf Res 15:185-212

Zhubkov MV, Lopez-Urrutia A (2003) Effect of appendicularians and copepods on bacterioplankton composition and growth in the English Channel. Aquat Microb Ecol 32: $39-46$

Submitted: August 23, 2005; Accepted: October 6, 2005 Proofs received from author(s): March 17, 2006 